\title{
Reunification in Korean Peninsula
}

\author{
Helal Uddin Ahmmed \\ Lecturer, Department of International Relations \\ University of Chittagong, Bangladesh \\ Email: helal.ir.cu@gmail.com \\ Md. Matiul Hoque Masud \\ Lecturer, Department of International Relations \\ University of Chittagong, Bangladesh \\ Email:masud.ir.cu@gmail.com \\ Md. Faisal \\ Assistant Professor, Department of International Relations \\ University of Chittagong, Bangladesh \\ Email: callazim@yahoo.com \\ Md. Niaz Morshed \\ Lecturer, Department of International Relations \\ University of Chittagong, Bangladesh \\ Email:nmripon@yahoo.com
}

Doi: 10.5901/mjss.2013.v4n4p217

\section{Abstract}

Everything has a time. After 60 years of division, two independent nations North and South Korea have missed their chance to be unified. It is not always true that the top leaders of the two states have no wish to bring their nations in one. This reunification process is very sensitive issue in the context of internal and external dynamics. Regional major powers and global superpowers have their own interest in these perspectives. None should make it a Zero-sum game. Major Powers believed the Status Quo will be better than the best option in this case. So every concerned power step slow-go policy. As the two nations did not break themselves, they could not be able to reunify it without help of other. To avoid any devastating situation in Korean Peninsula reunification process should be in diplomatic way. The purpose of this paper is to find out the possibility of their unification in future of course without denying the historical context. It also focuses major powers outlook in this process.

Key Words: Reunification, Integration, Nuclear Proliferation, Communism, Regional Cooperation.

\section{Introduction}

In the context of regional and international level the outcome of Korean reunification is very challenging that's why every engaged party want to take go-slow policy. If two states remain divided in bitter relations, it will hamper in regional and international integration. Their reunification hastens the world wide integration process. This reunification will be a model for states where civil war and secessionist movement is going on. We can not deny the possibility of reunification because of some ongoing process of the two nations. It is somewhat clear that two states want to unify but big powers do not want them to do so. Every major power will drop something if two states unify them in one state that they can not overlook. For their own interest, big powers will discourage two nations unify in one sovereign state. Bitter experience of past and unpredicted highway of future made the leaders of two nations to take "Not in my times" policy. The populace of 
the two states wants to live as they were. Now "386 generations"1 is more active to build their nations unified because this generation was not touched by the helping hand of America and China. The generations (interesting enough, South Korean born after 1960 accounted from $64 \%$ of the South Korean population in 2000) don't know what happened in the past (To note, from 1950 to 1953, 54000 American lost their lives to defend South Korea from North Korea and Chinese communist forces. ${ }^{2}$ The US has since poured more than $\$ 13$ billion in economic aid and military assistance in the country) it thinks what will occur in future.

This generation can not but unites for better future. The number of this generation is increasing from $24.3 \%$ (of the total population) in 1996 to $45.9 \%$ in 2004. ${ }^{3}$ On 19 December 2011 following Kim Jong IL's death, Kim Jong-un the third son of Kim Jong II is succeeded on the position whose age is around 30. This generation needs reunification, it does not matter what North Korea is doing, even, one week after the nuclear explosion a survey found that still 62 percent of the South Korean population wants economic integrity. ${ }^{4}$

Militarily powerful North and South which have unbound possibility to be Economic major power can give this generation something new. Vietnam, Yemen and Germany have broken into parts but they made themselves unified so, why not Korea? Their unification may bring some better option that can build a peaceful Korean Peninsula as well as North East Asia which will outnumber their problems that it creates.

Interestingly, these two independent states always show "welcome policy" toward big powers to solve their bilateral problems. Two nations cannot solve their bilateral problems without the assistance of major power which will be a foremost obstacle in their way to be unified. Unification process can be bilateral but its impact cannot be confined to that. Big powers will not come out of their own interest in solving Korean problem. Big power could not be able to export 'confidence building measures' in this context. Policy taken by top leaders of the two nations so far can't be succeeding in building unique state it should be more fruitful. It can't be thought that if any one of the states claim the unification that states would be inferior.

\section{Historical Background of the Issue}

Korean War was a regional problem with international ramification. From the time of the Qing Dynasty, China controlled Korea. Three wars have been fought on Korea that time by outsiders. The Japanese met the Chinese near Pyongyang in the Sino-Japanese war (1894-5). With the 'Treaty of Shimonoseki' on 17 April 1895, China renounced all influence in Korea. The weakness of China allowed Soviet Russia to build bases in Manchuria. Japan defeated Soviet Russia in Russo-Japanese war (1904-05). Korea had become a protectorate of the Japanese Empire and Japan colonized Korea in 1910. Following the Japanese surrender on the Korean peninsula in 1945 to the US in the South and the USSR in the North, the stage was set for the third war on Korean soil. The Republic of Korea (ROK) was established on 15 August 1948 under President Syngmen Rhee, the Democratic People's Republic of Korea (DPRK) on 09 September 1948 under Kim II Sung. ${ }^{5}$ The US withdrew its forces. South wanted to be unified but North had no wish to do so under the United Nation's guidance. On 25 June 1950, North attacked on the South Korea. In absence of Soviet delegates the UNSC passed resolution to kick North out of $38^{\text {th }}$ parallel. ${ }^{6}$ The ROK force fought as a part of the UN Command led by the US, and the DPRK fought with Russian equipment and later alongside Chinese Communist forces when UN forces threatened the Manchurian border. The final outcome was an armistice in 1953 where Rhee never signed.

Korean War proved that cold war may occur out of Europe and America. This war joined China actively in cold war race. It was a new dimension of cold war. Cold war was not always cold sometimes it becomes hot and Korean War was the new battleground for two ideologically rival groups. In south East and North East Asia communism was exported by USSR but it was tackled by China. USSR did not take part actively in preserving communist form of government in this area. In 1950s the form of communism in soviet Russia and China was totally different. Their motive was not same. Mao did not give oral support to Stalin who took policy against Lenin. Lenin thought communism has originated in USSR and it is only applicable in USSR not for anyone else but Stalin wanted to export communism to other countries. Chinese Communist Party got an exceptional support from root level people whereas soviet used elite group as spring board. Mao

\footnotetext{
1 "386 Generation" implies the population over 30 of their age and goes university in 1980s and born after 1960s after the Korean War. They didn't experience the War. See for details Sunhyuk Kim and Wonhyuk Lim, "How to deal with South Korea", The Washington Quarterly, 30:2, (spring 2007). P-74.

2 Kim and Lim, op.cit; p-78.

3 ibid, p.74

${ }^{4}$ Hahm Chaibong, The Two South Koreas: A House Divided, The Washington Quarterly, 28:3 (Summer, 2005), p. 63

5 Norman Lowe, "Mastering Modern World History", (New York: Palgrave, 1997) P-144

${ }^{6}$ lbid, 
had a vision to deploy communism in regional basis not international. Communist and capitalist blocs both were more successful in dividing ties and building their own satellite in Asia. Most of the Asian countries are relatively more motivated than other continents from communist and capitalist views. So, total Asia has become views importing zone.

\section{Reunification Process}

North Korea has taken first step towards reunification in August 1971, when its communist leaders arranged a Family Reunion Program on border. On $4^{\text {th }}$ July 1972 both the states took a three point's preamble known as "The North-South Joint Communiqué" to go forwards to be unified. It stated that reunification should be gained independently without foreign intervention and the process should be peaceful. Notable that, in 1970 a rapprochement process was going on between China and the United States of America. So, big powers bilateral relations have had an impact on Korea. In 1984 two states proposed a Memorandum of Understanding (MOU) to support each other in time of natural disaster. On the eve of 1990s at the time of soviet collapse North Korea thought now it has to safeguard itself that's why it ran out a nuclear project. By the time, two nations signed a Nuclear Non-aggression Pact in 1991. When Berlin wall was broken down, two states had no wish to follow Germany. In 1995, the then South Korean President under the auspices of the US ex-president Jimmy Carter took measures to build a warm relation with north. He took Sunshine policy and that policy suggests solving questionable issues. North Korean late-president Kim II sung has raised his famous three points reunification formula:

1. Building sovereignty, peaceful reunification and greater national unity

2. Building democratic federal republic of Korea

3. Building neutral state, development assistance, peaceful way to solve political clash, tribute respect for those who played role in reunification process, patriotism will be the slogan of unity

In April 1999, the Foreign Minister of respective nations declared that now they are not antagonistic to each other like in the past. In June of that year Vice Foreign Minister met and said they will not use their force against each other they will not allow any foreign state to interfere in their bilateral issues. In March 2000, the President of South proposed North economic recovery program to North. In June 2000 again South Korean President Kim Dae-Jung (1998-2003), for the first time in the history of 55 years, met together in Pyongyang. In May 2002, they met again. Present nuclear crisis has stopped the reunification process from then. Still in slow process the unification is going on. In inaugural address on February 25, 2003, South Korean President Roh Moo-hyun unveiled several principles that came to be known as the "Peace and Prosperity Policy". ${ }^{7}$ Unification minister under Roh, Chung Dong-young handover $\$ 100$ million in cash in Inter-Korean Dialogue in 2004. Defense Ministers meeting started on September, 25, 2000. Again they met in November 2007. Inter-Korean talk started on May 26, 2004. Inter-Korean prime Ministers meeting held in South Korea in November 2007, planned to set up a "Special Area for Peace and Cooperation in West Sea", organized a 'Joint Committee for North-South Economic Cooperation; Haeju special Economic Zone; Building a port ; reconstruction of the KaesongPyongyang highway; Kaesong-Sinuiju railway. ${ }^{8}$ Its second round held in 2008.

"Peace will definitely come" South Korean President Lee Myung-Bak said on the $65^{\text {th }}$ anniversary of the Korean's liberation from 35 years of Japanese colonial rule. ${ }^{9} \mathrm{He}$ proposed a special tax to finance the enormous cost of reunification with Korea. It is estimated that the cost of Korean reunification will be $\$ 25$ billion to $\$ 3.5$ trillion. ${ }^{10}$ In Dec 2007, Lee Mong Bake's government got 49 percent vote and elected President of South Korea. His party "Grand national Party" is recognized as anti-American. To note, 68 percent of South Korean population are progressive they want reunification. On 04 October, 2007, South Korean President Roh moo-hyun and North Korean leader Kim Jong II signed an 8 point Peace Agreement. In this agreement they proposed peaceful resolution of all contentious issues. Truly the process is slow going and is not enough to reunify them. Bilateral conflict and divergence in big powers interest is the main cause of Korean division yet.

\footnotetext{
7 Scott Snyder, "South Korea's Squeeze play". The Washington Quarterly, autumn 2005, 28:4, p-97.

8 So Ki Sok, "Reasons behind the stained Inter-Korean relations and ways to improve them", Asia Paper, Dec-2011; Institute for Security and Development policy. P-7

${ }^{9}$ Cheo Sang Hun," South Korean Leader Proposes a tax to finance reunification", The New York Times; August 15, 2010.

10 Colonel David Coghlan, "Prospects from Korean Reunification", a news letter from Strategic Studies Institute released in April, 2008. $P-3$. 


\section{Evaluating the Reunification Process: Still No Where}

Korean reunification process is not independent. Korean states want to implement the policy suggested by big powers. Two Korean states proposed unification through diplomatic mediating without using force but South Korean joint military exercise with the USA and North Korean nuclear project has intensified military race as well as has complicated to gain win-win situation through negotiation. Mainly the process is running at a snail's pace. Multiparty negotiation process has not been organized yet. Six Party Talks has eased the North Korean nuclear crisis so could be taken in case of reunification. The reunification proposal has not been drawn in any regional forum such as APEC, ASEAN. Absence of a common regional organization in North East Asia has made the process more problematical. Two Korean states are not independently capable to build a unified Korea which must be neutral. Proposals from regional and international major powers are not convincing because they are not sure about the future of reunified Korea. Still they are doing cost-benefit analysis. As a satellite state of capitalist and communist bloc their position will be unpredicted. The top leaders of two Korean states forecasted that solving bilateral problem after reunification will be even more difficult. 'Confidence Building Measures' has not shared yet so mutual confidence in future policy making is even lower. Korean leaders are using reunification process as a new issue for foreign intervention. Uneven economic and military progress has made Korean states more disappointed about their integration. How the integration of government, military, geography, national wealth and services should be implicated is not clear. So, the process is still nowhere.

\section{The Diverse Interest of Big Powers in Reunification Process}

Korea is described as a "Shrimp among Whales". Big powers' interest makes the reunification process more difficult. Two Germany have unified after the collapse of USSR, so why not about Korea? why doesn't the USA take initiative? The USA took normalization of relations policy against Vietnam; why not with North Korea? Answer is clear; interest varies from situation to situation. If two states unify themselves, the USA has to withdraw its near about 37000 soldiers from South Korea. So, the USA will lose one of its powerful standpoints in North East Asia and it will be then more difficult to check the rise of China. The US has served as a shield to protect South Korea over the past five decades in accordance with the 1954 Mutual Defense Treaty. Now South Korean experts think there is no need to be under the US security umbrella, we are able enough to safeguard us. In some point of South Korea people rallied against the US military presence. $63 \%$ of South Koreans have unfavorable feeling toward the US and $56 \%$ feel that anti-Americanism is growing in the ROK. ${ }^{11}$

If two states unified in one and soar out their nuclear program it will be a threat to Japan. To counter this challenges Japan will start to expose its hidden nuclear power. So, Japan will go out of the US security umbrella. An allout invasion of Japan by Korea is inevitable if Korea is unified. Therefore it is in Japan's best interest to help North Korea economically so that the Korean Peninsula remains divided as now. Korea is inseparable from Japan in the Japanese mind. Both states have economic and military power, if both of them unified, the US have to convince another extra big power like Russia, China to legitimate its worldwide work. If two states are unified they may follow "one state two system" like Sino-Hong Kong which will be out of the US views. As a neighboring country, China may impart assistance to them. Whether they will give up nuclearization process or not is illegible to the US so far.

As China was related in Korean crisis from the very first, its views are also important to be considered. A unified Korea with the US troops will be a combined force against China. "An Asian edition of NATO's eastward expansion" is always a threat to China because the US Secretary of Defense William Cohen reaffirmed the US position: "the US troops level in both Korea and Japan would remain unchanged even if the Korean peninsula were peacefully reunified". ${ }^{12}$ China could militarily intervene in this crisis if they foresaw that American interference would remain same after Korean reunification. ${ }^{13} \mathrm{After}$ the reunification of North and South Vietnam China has lost its significance in Indo-China area so it may be happened in case of Korean peninsula too. If two sovereign states unified, it is not sure that it will follow Chinese economic system. China will be criticized by global economic form if it interferes in Korean system of economics.

So, the current strategic calculation of the US and China on Korean reunification resulted in a typical "Prisoner's Dilemma Game", in which both player's best strategy in defection (i.e.-non-cooperation). There is no "enforcer" of cooperation in the game. See the result of cooperation and non-cooperation of the game in the beneath table:

11 Seung-Hwan kim, "Anti-Americanism in Korea", The Washington Quarterly, Winter 02-03, 26:1, p-109.

12 Shiping Tang, "A Neutral Reunified Korea: A Chinese View", The Journal of East Asian Affairs, voll-13, no-2 (winter, 1999). P-4

13 Wang, Fei-Ling, "Joining the Major Powers for Status Quo: China's views and policy on Korean Reunification", Pacific Affairs 72, No-

2. (Summer, 1999). P- 182. 


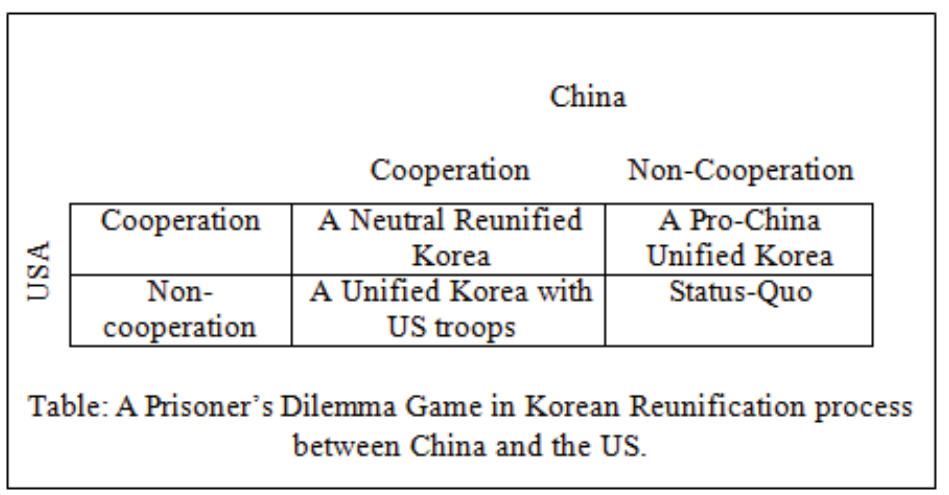

Source: Shiping Tang, "A Neutral Reunified Korea: A Chinese view". op.cit; p-14

In the Table we foresee that if two big powers cooperate in Korean Reunification a Neutral Reunified Korea will develop; if only one of them does not cooperate it will be dominated by the non-cooperated country; the other option is Status Quo if the two nations don't give proper support in this process.

China doesn't want to see Japan as emerging civilian nuclear power to counter the challenge of Korea. Bitter historical relations and continuing alliance with the USA have made Japan dependent for security state Japan has the capacity to build nuclear bomb within 19 days, if it does so, a new nuclear arms race will start in North East Asia.

China is also afraid of losing its unique control over South China Sea if Korea becomes capable to emerge itself as newly emerging power. China is keen to progress with "six party talks" when two states will be unified. May be Korea will not permit others to put their dirty nose in this issue, whether unified Korea will turn back and sign NPT or not is also unpredictable.

Japan believed that Korea once was a part of its' so this area can't be separated. To counter the foreign intervention in this region Japan historically used one foreign force against other. ${ }^{14}$ Until the Second World War, Korean peninsula was viciously dominated by Japanese Empire. Unstable situation at the time of Cold war made Japan conscious about its security. Japan wants to maintain reunification process diplomatically such as through Six Party Talks to avoid a Harsh-Landing Unification or Unification through military intervention. It mainly focuses on its economic interest. Unified Korea with the US troops and anti-Sino Korea will be big bazaar for its economic goods. Japan wants to use North and South Korea as buffer state against China. It also supports the military presence of the US in South Korea because it will feel more secure. After the Cold War, 9/11 in particular the US wants Japan to be self-dependent for its own security and burden sharing partner in war on terrorism, Nuclear Non-proliferation and newly created common problems. Japan wants to be stakeholder in security measures. The US encourages Japan to be nuclearized. Constitutional barrier, natural obstacles, bitter histories don't pave the way Japan to be so. It is undoubtedly clear that all of North East Asian countries prefer sound economic relations to military status quo. Every region has a multilateral economic community but North East Asian countries don't follow the way. Japan doesn't support the "Economic Embargo" strategy on North Korea for its rogue state like behavior.

As a neighbor country Russia has had interest in Korean peninsula. Unified Korea should be neutral -that is the prior objective in this issue. It just wants to maintain a balance of power between two states. Unified Korea with the US troops or Pro-Sino Korea both will be a new threat for Russia. Soviet Russia was involved in the first modern war in this region against Japan. After the Second World War, Soviet Union wanted to employ its own views to the area. Soviet Russia invested a huge amount to maintain its influence in Northern part. ${ }^{15}$ Soviet Union was concerned in Korean affairs in times of its division. North Korea was established as a truly communist state under the Soviet assistance. Treaty of Friendship, Cooperation and Mutual Assistance signed in 1961 authorized the Soviet Union to intervene in North Korean internal affairs. After the Cold war Russia wanted to keep balance of power between two Korean states as a result it gave

${ }^{14}$ Chae-Jin Lee, "US and Japanese policy toward Korean Reunification in US-Japan partnership in Conflict management: the case of Korea", The Keck Center for International and Strategic Studies,1993 p-4

15 Joseph P. Ferguson, "Perspectives on the future of Korean peninsula: Russia's role on the Korean peninsula and the Great power relations in the North-East Asia", The national Bureau of Asian research, 14, no-1, june-2003, p-35. 
support to North Korean nuclear project. Now Russia wants a peaceful reunification of Korean peninsula. The international community tries to use Russia as an essential mediator of Korean crisis.

\section{Obstacles on the way of Reunification}

Divergence in motive will be the foremost barrier to reunification. Actually, South Korea want to be reunified but North one is interested in building up a confederation where two nations will be sovereign but their economic military political and foreign policy will be same. Provincial election will determine which state will have the power to control whole country. Strategically, North Korea will control the whole country because it has more military than that of south it will not support it.

As two states have been getting used to two different economic systems for over 60 years they could not be able to give up their own logics. Cultural differences will be also a matter of conflict. It is well known that West Germany was interested in building united Germany. To be united it have to pay cost near about $\$ 500$ billion which is ten times larger than the national budget of South Korea. GNP of South Korea is only 25 percent of West Germany's. So South Korea will not be able to bear the cost of reunification.

There is no economic forum like EU in North East Asia which will impart help in that case. The people of South Korea don't permit to increase tax to pay the cost of reunification. Besides, there was no civil war between two Germany. In East Germany there were 360,000 Soviet troops but in Korean case it is not true.

North Korean Nuclear Crisis is also a problem in reunification process. To remind, When the US president declared it may use nuclear bomb to stop Korean War as early as possible from then and now North Korea wanted to develop its own nuclear project but this measures have taken the collapse of Soviet Russia as s turning point because it has lost its safeguard. After defying NPT in 1993, North Korea signed Agreed Framework in Clinton's era. ${ }^{16}$ Bush Administration has included North Korea in its "Rogue states" list. It is notable that 6 out of 10 citizens of South Korea think Bush administration should not include North Korea in its "Axis of Evil" list.

No state is secure in the new international order guided by the United States-argued by North Korea after the US leaded war against terrorism and their supporting failed states. To stop North Korean Nuclear crisis in 2003 North Korea, South Korea and China met in "Three party talk" and after its failure Russia, Japan and the US joined with them and started "six party talks". ${ }^{17}$ Absence of "politics of compromise" and mutual confidence let six party talks fail when on $9^{\text {th }}$ October North Korea exploded its first nuclear bomb. The explosion has ended the "six party talks". Now the North Korea using its nuclear power as leverage to blackmail and get a win- win situation in negotiation with big powers and regional power. On May 25, 2009, it has exploded its second nuclear bomb. If two states are unified North Korea will have to give up its military nuclear project this point has not been ever argued by six parties. North Korean nuclear crisis is still a barrier in reunification. That the United Korea should have nuclear power this fact is unavoidable, but unexpected for big powers.

The US military presence and Joint naval exercise with South Korea to combat North Korea is also an obstacle in unification. To note, the US-ROK Mutual Defense Treaty on October 1, 1953, paragraph 4 of this treaty grant the US the right to deploy the three military services anywhere in the South Korea and paragraph 6 legalize the US permanent stay in the South Korea and its automatic intervention in case of emergency on the Korean peninsula. ${ }^{18}$ It creates a security dilemma in this region. But 56 percent of South Korean population thinks "we no more need the US military". As a sequel the US in collaboration with South Korean forces carried out a Joint Naval Military Exercise on July 4, 2010, mobilizes both air and naval forces. This exercise involved forces ten times larger than earlier joint military exercise. It creates extra problem in the region because they are overestimating one another. On May 27, 2009, North Korea declared the Korean Armistice was no longer valid due to South Korean joining to "Proliferation Security Initiatives". In recent time an insurgency was occurred for the cause. Likewise- on November 23, 2010, North Korea fired about 170 rounds of artillery on Yeopyeong Island and the surrounding waters near the Yellow sea border. The South fired back. Former US President Jimmy Carter made a call for a peaceful solution.

This event made the process even intricate. The absence of common union in this region is also responsible for the time consuming process. In Europe, the EU has made a great role in German reunification. Two Korean states are still not member of any unique forum.

\footnotetext{
${ }^{16}$ Akl Kairouz, "North Korean nuclear crisis", Economic and Political Weekly, January 3, 2004, p-26.

17 Michael J. Mazarr, "The long road to Pyongyang", Foreign Affairs, Volume-86, No-5. P-87.

${ }_{18} \mathrm{Ho}$ Hak Rim, The conclusion of a Korean Peace Treaty and the US strategy in Asia Pacific Region, Asia paper, December, 2011. A news letter from Institute for Security and Development policy. P-7. 


\section{Policy Implications}

Major policy approaches should come from two Korean states themselves. They can build a combined unification ministry; they can raise fund to meet the cost. They can uphold the issue in front of international community. Under the guidance of UN good office they can run the process. North Korea has to give up its harsh policy. Peaceful measures should be taken to ease the situation. No one should take it as 'Zero-sum game'. "Unification with absorption" should be given up. They shouldn't over or under estimate other. They should not get ally militarily with regional or international power to win the race.

What the global and local powers can do that is by throwing their own interest into bin and compelled the two hostile roaring tigers to get into a single cage. To solve single most problems like North Korean nuclear crisis and joint military exercise the total international community should avoid two nations sponsoring negatively. APEC and ASEAN can provide policy approaches to solve the problem. Six Party Talks like multilateral diplomatic team can be organized to reunify two nations. In unification process an onlooker team can be sent to monitor the project. To escape from worst case scenario every state should come forward. "Soft Landing" (unification through diplomatic process) should get prefer than "Hard Landing" (unification through war or use of force). The US should ensure North Korea and China that the forces deployed in southern area will not be used against them. China and Japan should give more focus on economic ties and try to build a unique supranational organization to solve common problem. Russia may lose comparatively minimal to others. North Korea should not use its nuclear threat to blackmail international community. As South Korea is economically more stable and capable it should give economic assurance to Northern part that it will not face any problem like refugee and unemployment problem after unification. The generation after Kim Jong II may not use its nuclear ambition to gain more concession from international community.

\section{Conclusion}

The ongoing slow process shows that reunification will be time-consuming; not impossible. But the whole world is worried about the way how the event will happen. Reunification process should be neutral and must be in diplomatic way. Mutual concession can pave the way. Reunified Korea can build a stable and sound economic zone in North East Asia to overcome the hazardous situation. In context of international and regional politics, this reunification process is very demanding and vulnerable. If one state will collapse gradually and other one exercises its power on the falling state, it will create a worldwide dilemma. If at any cost by showing any cause a state start war against other one and it becomes regional or global nuclear war, it will also create worldwide problem. In that case the refugees will take shelter in the neighboring states. Economically the region will be catastrophic. Everyone has something to lose if the two states reunify in anytime through war. So, to avoid the upcoming crisis the world community should impart helping hand to support the voice of mass people of Korea.

\section{Bibliography}

Chaibong, Hahm, the Two South Koreas: A House Divided, the Washington Quarterly, 28:3 (summer, 2005)

Coghlan, David, "Prospects from Korean Reunification", a news letter from Strategic Studies Institute released in April, 2008.

Fei-Ling, Wang, "Joining the Major Powers for Status Quo: China's views and policy on Korean Reunification", Pacific Affairs 72, No-2. (Summer, 1999).

Ferguson P. Joseph, "Perspectives on the future of Korean peninsula: Russia's role on the Korean peninsula and the Great power relations in the North-East Asia", The national Bureau of Asian research, 14, no-1, (june-2003).

Hun, Sang. Cheo," South Korean Leader Proposes a tax to finance reunification", The New York Times; August 15, 2010.

Kairouz, Akl, "North Korean nuclear crisis", Economic and Political Weekly, January 3, 2004.

Kim, Sunhyuk and Lim, Wonhyuk, "How to deal with South Korea", The Washington Quarterly, 30:2, (spring 2007).

Lee, Chae-Jin, "US and Japanese policy toward Korean Reunification in US-Japan partnership in Conflict management: the case of Korea", The Keck Center for International and Strategic Studies, 1993.

Lowe, Norman, "Mastering Modern World History", (New York: Palgrave, 1997)

Mazarr, J. Michael, "The long road to Pyongyang", Foreign Affairs, Volume-86, No-5.

Rim, Ho Hak, The conclusion of a Korean Peace Treaty and the US strategy in Asia Pacific Region, Asia paper, December, 2011. A news letter from Institute for Security and Development policy.

Seung-Hwan, Kim, "Anti-Americanism in Korea", the Washington Quarterly, winter 02-03, 26:1,

Snyder, Scott, "South Korea's Squeeze play". The Washington Quarterly, autumn 2005, 28:4, 
Sok, Ki. So, "Reasons behind the stained Inter-Korean relations and ways to improve them", Asia Paper, Dec-2011; Institute for Security and Development policy.

Tang, Shiping, "A Neutral Reunified Korea: A Chinese View", The Journal of East Asian Affairs, voll-13, no-2 (winter, 1999). 